\title{
COMPARATIVE ANALYSIS OF THE ANTICANCER ACTIVITY OF ANGIOTENSIN RECEPTOR BLOCKERS - IRBESARTAN AND TELMISARTAN
}

\author{
PUNNAGAI K ${ }^{1}$, VIJAYBABU $\mathrm{K}^{2 *}{ }^{2}$, GLORY JOSEPHINE I ${ }^{3}$, DARLING CHELLATHAI DAVID ${ }^{1}$ \\ ${ }^{1}$ Department of Pharmacology, Sri Ramachandra Medical College and Research Institute, Chennai, Tamil Nadu, India. ${ }^{2}$ Department of \\ Pharmacology, Annapoorna Medical College and Hospital, Salem, Tamil Nadu, India. ${ }^{3}$ Department of Pharmacology, Sree Balaji Medical \\ College and Hospital, Chennai, Tamil Nadu, India. Email: drvijaymd@hotmail.com
}

Received: 14 June 2018, Revised and Accepted: 10 August 2018

ABSTRACT

Objective: Angiotensin receptor blockers (ARBs) are effective hypertensive drugs. Reduction in risk of lung cancer with ARBs was proven in clinical studies. Telmisartan and irbesartan are the second-generation ARBs. This study screens the anticancer activity of these two drugs in a dose-dependent manner using A549 cell line.

Methods: Different concentrations of irbesartan and telmisartan were treated on A549 cells and the anticancer activity was evaluated through methylthiazolyldiphenyl-tetrazolium [3-(4,5-dimethylthiazol-2-yl)-2,5-diphenyltetrazolium bromide] cytotoxicity assay. The dot plot of the cytotoxicity results was used to extrapolate the half maximal inhibitory concentration (IC50) values. Microscopic changes in the cells post-treatment with these drugs were also recorded at ideal concentrations.

Results: A reduction in cell viability was noted in A549 cells with increasing concentration of the drug. The IC50 values for irbesartan and telmisartan were $31.1 \mu \mathrm{g}$ and $15.6 \mu \mathrm{g}$, respectively. Microscopic observation of the cells shows more rounded and deformed dead cells on telmisartan- and irbesartan-treated cells when compared with the untreated control.

Conclusion: The results confirm the anticancer activity of both the drugs with telmisartan being more efficient. The anticancer activity could probably be due to the role of irbesartan and telmisartan in inhibiting mitogen-activated protein kinase cell survival pathway and local angiogenesis.

Keywords: Methylthiazolyldiphenyl-tetrazoliumbromide assay, Irbesartan, Telmisartan, Cytotoxicity, Angiotensin receptor blockers.

(C) 2018 The Authors. Published by Innovare Academic Sciences Pvt Ltd. This is an open access article under the CC BY license (http://creativecommons. org/licenses/by/4. 0/) DOI: http://dx.doi.org/10.22159/ajpcr.2018.v11i12.27948

\section{INTRODUCTION}

Angiotensin receptor blockers (ARBs) are antagonists to angiotensin II as it binds to angiotensin II receptor type I and blocks vasoconstriction, retention of sodium and water, cell proliferation, aldosterone release, and sympathetic nerve activation [1,2]. ARBs are safe approved drugs since the 1990s widely used to treat atherosclerosis, cardiovascular diseases, and blood pressure and have been included in commonly prescribed drug for the treatment of hypertension [3,4]. Losartan, candesartan, telmisartan, valsartan, and irbesartan are few of the approved ARBs. Telmisartan and irbesartan are metabosartans classified under the second-generation ARBs with a protective effect on diabetic nephropathy [5]. Adding on telmisartan has also substantially proven neuroprotective effects by possessing anti-inflammatory properties, in stroke patients [6].

There were conflicting reports on the association of ARBs with cancer. Candesartan in heart failure assessment of reduction in mortality and morbidity study showed that there were more fatal cancers in patients administered candesartan than placebo [7]. Meta-analysis using randomized controlled trials performed by Sipahi et al. [8] reported association of unassuming increased risk of new cancer diagnosis and ARBs. Later, a cohort study observed an apparently protective association between the use of ARBs and lung cancer [9]. Another metaanalysis study reported decreased lung cancer risk with ARBs [10].

Lung cancer prevalence among newly diagnosed cases of cancer and cancer deaths constitutes $13 \%$ and $19 \%$, respectively, worldwide [11]; $6.9 \%$ and $9.3 \%$, respectively, in India [12]. Its prevalence and mortality are due to lack of early detection of the illness, which risks the patient's life [13]. Due to the association of ARBs to lung cancer, the present study aims to demonstrate the anticancer activity of the two drugs telmisartan and irbesartan using methylthiazolyldiphenyl-tetrazolium bromide (MTT) assay on cell lines. A lung cancer cell line human lung alveolar epithelial cells derived carcinoma cell line A549 was used for analysis. Telmisartan and irbesartan were added to A549 cells at different concentration to determine the effect of these drugs on cancer cell viability in a dose-dependent manner.

\section{METHODS}

\section{Cell line and culture}

A549 cell line was provided by the National Centre for Cell Sciences, Pune. The cells were cultured and maintained in cell culture media, minimal essential medium (MEM) composed with antibiotics such as streptomycin $(100 \mu \mathrm{g} / \mathrm{ml})$ and penicillin $(100 \mathrm{U} / \mathrm{ml}), 10 \%$ fetal bovine serum (FBS) in a suitable temperature $\left(37^{\circ} \mathrm{C}\right)$, and atmosphere $(5 \%$ $\mathrm{CO}_{2}$ ).

\section{Reagents}

FBS and MEM were purchased from Cistron Laboratories (Chennai, India) and Hi-Media Laboratories (Mumbai, India), respectively. Dimethyl sulfoxide (DMSO), MTT, and trypsin were obtained from Sisco Research Laboratory Chemicals (Mumbai, India). Other reagents and chemicals were provided by Sigma-Aldrich (Mumbai).

\section{MTT Cytotoxicity assay}

The MTT assay for determining the tumor cell cytotoxicity of the two drugs was performed according to the method of Mosmann [14]. Briefly, cells $(1 \times 105 /$ well $)$ were plated in 24 -well plates and incubated at $37^{\circ} \mathrm{C}$ with $5 \% \mathrm{CO}_{2}$ atmosphere. On reaching confluence, the cells were washed in phosphate-buffered saline (PBS) and the medium was 
changed. Increasing concentrations of both the drugs obtained through serial dilution were added to the different wells and were marked, respectively. One of the wells was treated only with the diluent which served as the control. Cell control and drug control were included in each assay. The culture plates were kept under incubation for $24 \mathrm{~h}$ at $37^{\circ} \mathrm{C}$ with $5 \% \mathrm{CO}_{2}$ atmosphere. The medium was separated from wells after incubation, then PBS with pH 7.4 was used for washing the cells. $100 \mu \mathrm{l} /$ well of $0.5 \%$ MTT ( $5 \mathrm{mg} / \mathrm{ml}$ ) was added to each well and the cell plate was kept under incubation for $4 \mathrm{~h}$. After incubation, $1 \mathrm{ml}$ of DMSO was added in all the wells. This helps in dissolving the insoluble crystalline formazan product for effective absorbance measurement. UV spectrophotometry was used to measure the absorbance at $570 \mathrm{~nm}$; taking DMSO as blank, and the results were tabulated using the formula as follows:

$\%$ Cell viability $=\frac{\begin{array}{l}\text { A5s } 54 \text { cells } \\ \text { Absorbance of Control } \\ \text { A549 cells }\end{array}}{2100}$

\section{RESULTS}

The absorbance results of MTT assay and the resultant cell viability percentage are tabulated in Table 1 for telmisartan and Table 2 for irbesartan.

Half maximal inhibitory concentration (IC50) level of irbesartan was $31.2 \mu \mathrm{g}$ and that of telmisartan was $15.6 \mu \mathrm{g}$, respectively. This suggests that telmisartan is more cytotoxic than irbesartan. MTT cytotoxicity assay reveals an increase in cell death corresponding to an increase in the concentration of both irbesartan and telmisartan.

Effect of the drug telmisartan and irbesartan on the A549 cells was observed in a phase contrast microscope, and the results are presented in Fig. 1 (telmisartan) and Fig. 2 (irbesartan).

\section{DISCUSSION}

Our study proves the anticancer activity of these antihypertensive drugs. Both the drugs were able to establish a good cytotoxicity at lower concentrations indicating that more studies on this field will potentially establish an effective anticancer drug for treating lung cancers. The dot plots of the MTT assay reveal a steep decrease in the cell viability with increasing concentrations of both telmisartan and irbesartan. On extrapolating the IC50 values from the graph, it is shown that telmisartan is more effective than irbesartan. Almost half the concentration of telmisartan $(15.6 \mu \mathrm{g} / \mathrm{ml})$ was able to establish the IC50 when compared to irbesartan $(31.2 \mu \mathrm{g} / \mathrm{ml})$. This suggests that telmisartan will be a better drug of choice for future study. Microscopic observation showed a clear decrease in the live cells when compared to control at the IC50 concentration. Dead cells were seen with distorted and rounded morphology. There were few live elongated cells with normal morphology in Panel D and Panel C while there were no live cells at all in Panel B in comparison with Panel A. This was true for both telmisartan and irbesartan. This clearly shows that the drugs can induce cell death in these lung cancer cell models and thereby can stand as an effective anticancer drug.

Previous studies on telmisartan and irbesartan have demonstrated their ability to block cell proliferation in a dose-dependent manner. This property of these drugs was found to be due to its ability to block extracellular signal-regulated kinase (ERK) activation in aortic vascular smooth muscle [15]. ERK is one of the major mitogen-activated protein kinase (MAPK) signals that the cancer cells use for cell proliferation [16]. This could probably be the reason for the anticancer property noted in our study. More study in this line is required to demonstrate the involvement of MAPK signals in telmisartan- and irbesartaninduced anticancer activity. Further, the effect of irbesartan in blocking hypoxia-induced angiogenesis has also been reported [17].
Table 1: Effect of various concentrations of telmisartan on the cell viability of A549 cell line

\begin{tabular}{lllll}
\hline S. No. & $\begin{array}{l}\text { Concentration } \\
(\boldsymbol{\mu g} / \mathbf{m l})\end{array}$ & Dilutions & $\begin{array}{l}\text { Absorbance } \\
(\mathbf{O . D})\end{array}$ & $\begin{array}{l}\text { Cell viability } \\
(\%)\end{array}$ \\
\hline 1 & 1000 & & 0.12 & 16.66 \\
2 & 500 & $1: 1$ & 0.17 & 23.61 \\
3 & 250 & $1: 2$ & 0.21 & 29.16 \\
4 & 125 & $1: 4$ & 0.26 & 36.11 \\
5 & 62.5 & $1: 8$ & 0.30 & 41.66 \\
6 & 31.2 & $1: 16$ & 0.33 & 45.83 \\
7 & 15.6 & $1: 32$ & 0.36 & 50.00 \\
8 & 7.8 & $1: 64$ & 0.44 & 61.11 \\
9 & Cell control & - & 0.72 & 100 \\
\hline \multicolumn{2}{l}{ O.D: Optical density } & &
\end{tabular}

O.D: Optical density

Table 2: Effect of various concentrations of irbesartan on the cell viability of A549 cell line

\begin{tabular}{lllll}
\hline S. No. & $\begin{array}{l}\text { Concentration } \\
(\boldsymbol{\mu g} / \mathbf{m l})\end{array}$ & Dilutions & $\begin{array}{l}\text { Absorbance } \\
(\mathbf{O . D})\end{array}$ & $\begin{array}{l}\text { Cell } \\
\text { viability (\%) }\end{array}$ \\
\hline 1 & 1000 & Neat & 0.09 & 12.50 \\
2 & 500 & $1: 1$ & 0.15 & 20.83 \\
3 & 250 & $1: 2$ & 0.24 & 33.33 \\
4 & 125 & $1: 4$ & 0.27 & 37.50 \\
5 & 62.5 & $1: 8$ & 0.32 & 44.44 \\
6 & 31.2 & $1: 16$ & 0.37 & 51.38 \\
7 & 15.6 & $1: 32$ & 0.40 & 55.55 \\
8 & 7.8 & $1: 64$ & 0.42 & 58.33 \\
9 & Cell control & - & 0.72 & 100 \\
\hline
\end{tabular}

O.D: Optical density

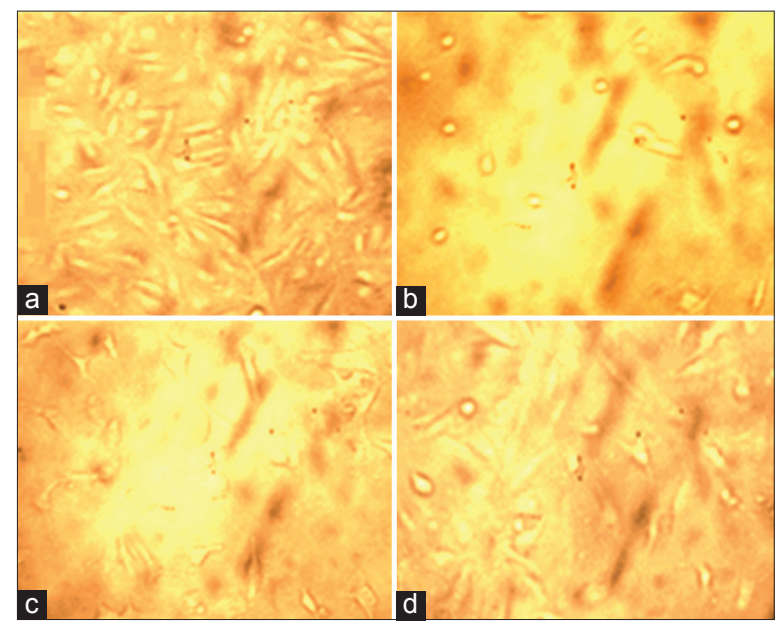

Fig. 1: Microscopic observation of the telmisartan-treated A549 cell line. Panel A represents the control untreated cells, the control panel shows more viable elongated slender healthy cells Panel B represents treatment with $1000 \mu \mathrm{g} / \mathrm{ml}$ of the drug, this being the maximal drug concentration shows no viable cells in the field; Panel C represents treatment with $31.2 \mu \mathrm{g} / \mathrm{ml}$ of the drug, this shows very few cells on the whole in the field with more distorted and apoptotic morphology; and Panel D represents

$15.6 \mu \mathrm{g} / \mathrm{ml}$ of the drug, being the half maximal inhibitory concentration, it shows the presence of few dead cells and few live cells

The main reasons for cancer cell survival and proliferation are increased local angiogenesis [18,19], growth suppressor evasion, cell death inhibition, and increased activation of MAPK survival pathway which keeps the cells always in the proliferative phase, 


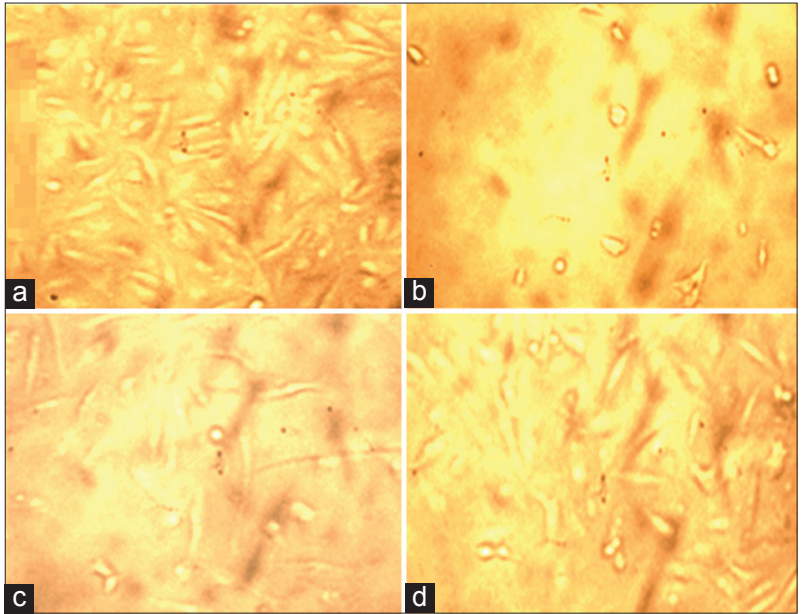

Fig. 2: Microscopic observation of the effect of irbesartan on A549 cell line. Panel A represents the control untreated cells with more live cells showing a healthy morphology, Panel B represents treatment with $1000 \mu \mathrm{g} / \mathrm{ml}$ of the drug with a meager few dead cells on the field, Panel C represents treatment with $62.5 \mu \mathrm{g} / \mathrm{ml}$ of the drug showing extended dying cells and rounded dead cells in the field, and Panel D represents $31.2 \mu \mathrm{g} / \mathrm{ml}$ of the drug, it shows the presence of few dead cells and few live cells

thus promoting the cancerous property [20]. This uncontrolled cell growth, activation of invasion and metastasis, and host immunity avoidance are few of the other properties that retain the cancerous nature of these cells [21]. Nowadays, surgery, chemotherapy, radiation, hormones, and immunotherapy are the main approaches for the cancer treatment. Several problems are associated with the existing treatment methods which include limited efficacy, severe toxicity, and multidrug resistance [22]. This work is the first of its kind in demonstrating the anticancer activity of telmisartan and irbesartan in a dose-dependent manner. These antihypertensive drugs have been found to have inhibitory roles on the two key processes of cancer, i.e., angiogenesis and MAPK pathway and thus can stand as an effective anticancer drug. This will pave the way for generating novel anticancer drugs with the drugs existing in the market which are relatively less toxic and more effective. The in vitro screening of drugs for anticancer activity is technically simple, quick, cost-effective, and reproducible and provides information about the targets of anticancer action. However, this method has its own limitations as it is error prone and only few molecules reach the human clinical trials. Hence, we need to further extend the study in various in vitro methods and in vivo experimentation in animal models of cancer [23].

\section{CONCLUSION}

The study drugs ARBs telmisartan and irbesartan show anticancer activity on the A549 lung carcinoma cell lines. These study results establish a good anticancer activity at lower concentrations of these drugs indicating that more studies on this field are further needed to establish their molecular mechanism of action and to substitute them as effective adjuvant anticancer drugs for lung carcinoma and other cancers which might be safe, tolerable, and effective.

\section{ACKNOWLEDGMENT}

The authors thank the faculty of the Department of Pharmacology, Annapurna Medical College and Sri Ramachandra Medical College, for their support to conduct the study.

\section{AUTHORS' CONTRIBUTION}

Dr. K. Punnagai (first author): Conceived the idea, planned the experiments, procured the required cell lines, and analyzed the data and graphs.
Dr. K. Vijaybabu (second author and corresponding author): Planned the experiments and conducted the experiments and helped in the calculation of IC50 values and communication with the publication.

Dr. I. Glory Josephine (third author): Added valuable contribution to the conduction of experiments and writing of the manuscript along with the coauthors.

Dr. D. Darling Chellathai (fourth author): Supervised the experiments with necessary laboratory requirements and sample preparation and manuscript editing.

\section{CONFLICTS OF INTEREST}

The authors declared that they have no conflicts of interest.

\section{REFERENCES}

1. Barreras A, Gurk-Turner C. Angiotensin II receptor blockers. Proc (Bayl Univ Med Cent) 2003;16:123-6.

2. de Gasparo M, Catt KJ, Inagami T, Wright JW, Unger T. International union of pharmacology. XXIII. The angiotensin II receptors. Pharmacol Rev 2000;52:415-72.

3. Sleight P, Jakobsen A, Heroys J, Ralph A, Rees T, Shaw M, et al. No HOPE without proof: Do ARBs meet the standard for cardiovascular protection? Medscape J Med 2008;10 Suppl: S6.

4. Soubra L, Nureddin H, Omar A, Saleh M. Factors associated with hypertension prevalence and control among lebanese Type 2 diabetic patients. Int J Pharm Pharm Sci 2018;8:153-9.

5. Nakagami H, Kiomy Osako M, Nakagami F, Shimosato T, Minobe N, Moritani $\mathrm{T}$, et al. Prevention and regression of non-alcoholic steatohepatitis (NASH) in a rat model by metabosartan, telmisartan. Int J Mol Med 2010;26:477-81.

6. Jose A, Wilson D, George M, Reshma K Thomas R, Justin A. Comparative study on the beneficial effects of telmisartan and other antihypertensive agents in stroke patients. Int $\mathrm{J}$ Pharm Pharm Sci 2017;9:99-102

7. Pfeffer MA, Swedberg K, Granger CB, Held P, McMurray JJ, Michelson EL, et al. Effects of candesartan on mortality and morbidity in patients with chronic heart failure: The CHARM-overall programme. Lancet 2003;362:759-66.

8. Sipahi I, Debanne SM, Rowland DY, Simon DI, Fang JC. Angiotensinreceptor blockade and risk of cancer: Meta-analysis of randomised controlled trials. Lancet Oncol 2010;11:627-36.

9. Bhaskaran K, Douglas I, Evans S, van Staa T, Smeeth L. Angiotensin receptor blockers and risk of cancer: Cohort study among people receiving antihypertensive drugs in UK general practice research database. BMJ 2012;344:e2697.

10. Zhang J, Liu J, Chen J, Li X, Wu Y, Chen H, et al. Angiotensin receptor blockers (ARBs) reduce the risk of lung cancer: A systematic review and meta-analysis. Int J Clin Exp Med 2015;8:12656-60.

11. Ferlay J, Soerjomataram I, Ervik M, Dikshit R, Eser S, Mathers C, et al. International Agency for Research on Cancer; 2013. GLOBOCAN. Vol. 1 0. Cancer Incidence and Mortality Worldwide. Lyon, France: IARC Cancer Base; 2012.

12. Indian Council of Medical Research; 2013. National Cancer Registry Programme. Three Year Report of Population Based Cancer Registries; 2009-2011.

13. Ford DW, Koch KA, Ray DE, Selecky PA. Palliative and end-of-life care in lung cancer: Diagnosis and management of lung cancer, $3^{\text {rd }}$ ed: American college of chest physicians evidence-based clinical practice guidelines. Chest 2013;143:e498S-e512S.

14. Mosmann T. Rapid colorimetric assay for cellular growth and survival: Application to proliferation and cytotoxicity assays. J Immunol Methods 1983;65:55-63.

15. Yamamoto K, Ohishi M, Ho C, Kurtz TW, Rakugi H. Telmisartaninduced inhibition of vascular cell proliferation beyond angiotensin receptor blockade and peroxisome proliferator-activated receptorgamma activation. Hypertension 2009;54:1353-9.

16. Roovers K, Assoian RK. Integrating the MAP kinase signal into the G1 phase cell cycle machinery. Bioessays 2000;22:818-26.

17. Rakusan K, Chvojkova Z, Oliviero P, Ostadalova I, Kolar F, Chassagne C, et al. ANG II type 1 receptor antagonist irbesartan inhibits coronary angiogenesis stimulated by chronic intermittent hypoxia in neonatal rats. Am J Physiol Heart Circ Physiol 2007;292:H1237-44

18. Holmgren L, O’Reilly MS, Folkman J. Dormancy of micrometastases: 
Balanced proliferation and apoptosis in the presence of angiogenesis suppression. Nat Med 1995;1:149-53.

19. Parangi S, O’Reilly M, Christofori G, Holmgren L, Grosfeld J, Folkman J, et al. Antiangiogenic therapy of transgenic mice impairs de novo tumor growth. Proc Natl Acad Sci U S A 1996;93:2002-7.

20. De Luca A, Maiello MR, D’Alessio A, Pergameno M, Normanno N. The RAS/RAF/MEK/ERK and the PI3K/AKT signalling pathways: Role in cancer pathogenesis and implications for therapeutic approaches.
Expert Opin Ther Targets 2012;16 Suppl 2:S17-27.

21. Hanahan D, Weinberg RA. Hallmarks of cancer: The next generation. Cell 2011;144:646-74.

22. Tan W, Lu J, Huang M, Li Y, Chen M, Wu G, et al. Anti-cancer natural products isolated from Chinese medicinal herbs. Chin Med 2011;6:27.

23. Ahmed SN, Das B, Chakraborty J. Prospective and retrospective animal model used in the pharmacological screening of anti-cancer drug. Int $\mathrm{J}$ Curr Pharm Res 2018;10:13-8. 